The American Journal of Political Science Law and Criminology

(ISSN - 2693-0803)

VOLUME 04 ISSUE 01 Pages: 47-51

SJIF IMPACT FACTOR (2020: 5. 453) (2021: 5. 952)

OCLC - 1176274523 METADATA IF - 7.659

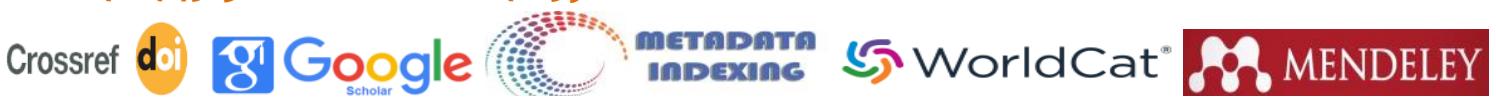

Research Article

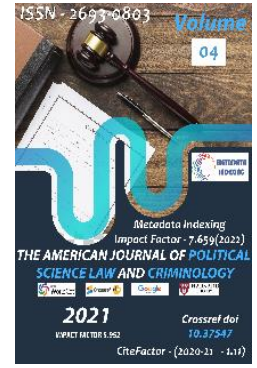

Journal Website: https://theamericanjou rnals.com/index.php/ta jpslc

Copyright: Original content from this work may be used under the terms of the creative commons attributes 4.0 licence.

\section{SECURITIES MARKET LAW AS A NEW COMPLEX BRANCH OF LAW IN THE REPUBLIC OF UZBEKISTAN}

\author{
Submission Date: January 09, 2022, Accepted Date: January 20, 2022, \\ Published Date: January 30, 2022 \\ Crossref doi: https://doi.org/10.37547/tajpslc/Volume04Issue01-08 \\ Batirova Kamolakhon \\ Lecturer of the Business law department of Tashkent state university of law, Uzbekistan
}

\title{
ABSTRACT
}

This article is aimed to study of trends in the development of securities market law in the Republic of Uzbekistan. The author analyzed the theoretical foundations of the securities market law as a complex branch of law and studied the experience of foreign countries in this area. Also, in the article the author analyzes the connection between the securities market law and other branches of law, such as civil law, financial law and corporate law.

\section{KEYWORDS}

Securities, shares, securities market law, legal relations, securities transactions, development, stock exchange, branch of law.

\section{INTRODUCTION}

Nowadays, it is impossible to imagine the structure of the financial market of any developed country without the securities market, which in some of them even plays the most crucial role. Also, the securities market in the modern world accounts for a significant part of the gross domestic product of these mentioned countries. For this reason, our country has also paid considerable attention to the development and support of this part of the financial market in recent years. Although the securities market of the Republic of Uzbekistan has been alive for many years. However, it remains not relevant and not interesting for potential 
The American Journal of Political Science Law and Criminology (ISSN - 2693-0803)

VOLUME 04 ISSUE 01 Pages: 47-51

SJIF IMPACT FACTOR (2020: 5. 453) (2021: 5. 952)

OCLC - 1176274523 METADATA IF - 7.659

investors and issuers themselves. However, at the present stage, the development of the market is brought up at the level of state policy. A bright example of these words is organization of the Tashkent International Financial Center (TIFC) with the support of the British government .

Also, the Uzbek government has adopted laws and regulations with the aim of eliminating weaknesses and developing the national market in recent years. Nowadays, Uzbek securities market is regulated by over 50 legal acts, adopted by different government bodies. However, these efforts remain one-sided, as the theoretical foundations of securities regulation are not studied at all by legal scholars. Although, if you look at the experience of foreign countries, the theoretical basis of this branch of law is actively developing in parallel with the practical aspect and is even considered independent. Although this branch of law is named differently in academic papers of various legal scholars: securities law, securities market law, stock exchange law, capital market law, corporate finance law.

In our opinion, this variation in the name of the industry is explained by the difference in legislation and the specific practice of the securities market of the authors' countries of origin.

As far as our national legal system is concerned, it is more appropriate to introduce such a variant of the ones as mentioned above as "Securities Market Law". Several reasons contributed to this choice:

- Analyzing uzbek securities market, there is significant role of Over-The-Counter Market, because only almost one-fifth of the national jointstock companies sell their shares on the stock exchange (the total number of JSC Uzbekistan 603 , number of publicly traded joint stock companies- 139 , also confirming the fact is, not only the number of listed companies but also figures for the last 9 months, the volume of OTC transactions has accounted for 874,13 billion, while on the stock exchange, the volume of securities transactions has reached 975,0 billion)

- Uzbek national securities market includes both corporate and government securities, for this reason, it would not be quite correct to concern in only the legal relations with corporate financial instruments as the subject of the field, called of the industry, "Corporate Finance". which abroad not only regulates the relations connected with securities and other financial matters of the company;

- The branch of law regulates relations not only on securities but also indirect legal relations: between the issuer and the investor, the owner, the status and relations of professional participants, etc. For this reason, the name "securities law" would make the circle of relations very narrow.

Also, in this issue, it is necessary to pay attention to the presence of two very similar concepts: the stock market and the securities market, since in the correct naming of the industry it is necessary to start from the concept itself. According to many scientists, these concepts are equivalent and can be used as synonyms.

However, there is a different point of view about the meaning of these terms. One example of this approach in differences is the opinion of the Ukrainian economist A. A. Peresada, who believes that the securities market consists of two parts : the stock market and the sphere of securities circulation in the form of purchase and sale of short-term (up to one year) documents. Thus, according to this author, the concept of the securities market is broader than the concept of the stock 
The American Journal of Political Science Law and Criminology (ISSN - 2693-0803)

VOLUME 04 ISSUE 01 Pages: 47-51

SJIF IMPACT FACTOR (2020: 5. 453) (2021: 5. 952)

OCLC - 1176274523 METADATA IF - 7.659

market. At the same time, the special role of the stock market in the development of market relations is noted since it is on it that stocks and bonds are traded. It is no coincidence that most foreign and domestic experts' research and mathematical justifications are devoted to the stock market.

The securities market law has a close connection with many other branches of law. However, according to the results of comparative analysis, the securities market law has a more practical character than other branches of law. And this utilitarian side of this field helps to facilitate the process of making rational decisions for any company in the securities market. It is based on essential rules that exist in traditional areas of law. According to Petri Mantysaari, for the legislator, each of the traditional areas of law has its functions and aims, and the legislator's preferences in one area (say, corporate law) do not necessarily coincide significantly with his preferences in another area (for example, financial interests), because the relevant interests vary depending on the context .

The securities market law has all those features of a complex branch of law that distinguish it from an independent branch and sub-branch of law. Securities market law and other complex branches connect various institutions of specialized branches such as environmental, information, and business law.

This branch includes institutions of both public and private law, such as financial law, civil law, corporate law, and business law.

Some legal relations are related to the turnover of government securities, then in this case, there are also public legal relations regulated by financial law. The role of administrative law in regulating such relations in the securities market is also clearly expressed. According to E.V.Zenkovich, the specifics of administrative property relations in the securities market may consist in the participation of public legal entities and public authorities acting on their behalf in property (civil) turnover and consolidation by bylaws (in addition to the Civil Code). of the Russian Federation and legislative acts) of certain advantages over other participants in civil traffic .

On the other hand, it is impossible to deny the existence of property relations, which are closely regulated by the branches of private law. For example, securities transactions are the part of civil law. To be more precise, these are public legal relations that arise between equal participants in the securities market and have equal rights and obligations, the subject of which is such financial instruments as securities. Among the features that distinguish civil legal relations from other types of legal considerations, O. S. Ioffe also refers to: the method of protecting civil rights, the grounds for the emergence of civil legal concerns, the civil-dispositive nature of norms, and unique ways to terminate a legal relationship.

The role of civil law in the institution of transactions with securities is that all those transactions concluded on the securities market must meet the requirements of this branch of law. However, this fact does not detract from the uniqueness of such transactions. Unlike other civil transactions, securities transactions have their characteristics, which are not at all the subject of civil law. For example, by their legal nature, such transactions require the participation of financial intermediaries, or shares transactions of listed companies must be concluded only through the exchange.

To a greater extent, such an independent branch of law as corporate law also impacts our studied branch of law. Analysis of trends in legal relations on the national securities market proves that corporate law 
The American Journal of Political Science Law and Criminology (ISSN - 2693-0803)

VOLUME 04 ISSUE 01 Pages: 47-51

SJIF IMPACT FACTOR (2020: 5. 453) (2021: 5. 952)

OCLC - 1176274523 METADATA IF - 7.659

Crossref do

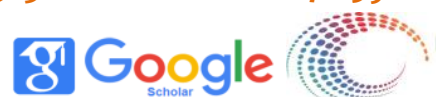

metapดTa

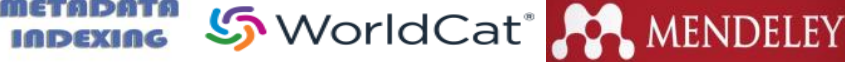

Publisher: The USA Journals

establishes the beginning of the above-mentioned legal relations. Corporate law acts, in this case, as a kind of progenitor of legal concerns related to securities, since the evolution of corporate associations and corporations, in general, has contributed to the emergence and development of the securities market. In addition, corporate relations are complicated by such legal categories as shares, which are objects of the securities market.

Based on the analysis of connection and mutual influence between corporate law and securities market law, it is necessary to list examples when legal relations include institutions of both branchs:

1. Acquisition of the "Publicity" status by the joint-stock company. In this case, a joint-stock company becomes public through an initial public offering. That is, its shares become available for purchase on the stock exchange.

1. One-sided or cross-ownership of shares.

2. Protection of the rights and legitimate interests of shareholders, as well as minority shareholders.

3. Exercise of rights to shares on the securities market.

4. $\quad$ Procedure for transferring rights to shares.

Summarizing all of the above, we can say that the Republic of Uzbekistan intends to develop the national securities market and, for this purpose, is developing a regulatory and legal framework. However, it is impossible to present development from a legal point of view only in a practical aspect. For this reason, the article notes the significant role of the study of the theoretical foundations of the law of the securities market. And on the basis of everything, we propose to introduce securities market law as an optional subject for law students.

\section{REFERENCES}

1. Отчет Британско-Узбекской рабочей группы по МФЦ. http://cmda.gov.uz/userfiles/files/files1/UKUzbekistan\%2olFC\%20Working\%20Group\%20Report $\% 2$ C.pdf

2. Батирова К. ПРАВОВЫЕ ОСОБЕННОСТИ ИСЛАМСКИХ ЦЕННЫХ БУМАГ (СУКУК) //Review of law sciences. - 2020. - Т. 2. - №. Спецвыпуск.

3. The Law of Security and Title-Based Financing. Third Edition. Hugh Beale, Michael Bridge, Louise Gullifer, and Eva Lomnicka. Oxford University Press; 2nd edition (May 16, 2012). English. Hardcover : 975 pages

4. Stock Exchange Law: Concept, History, Challenges . Andreas M. Fleckner, Klaus J. Hopt. Max Planck Private Law Research Paper No. 14/4 law, corporate finance

5. Rüdiger VEIL. European capital markets law. Oxford ; Portland, Oregon : Hart Publishing, 2017, $788 \mathrm{p}$.

6. Petri Mantysaari. The Law of Corporate Finance: General Principles and EU Law. Volume I: Cash Flow, Risk, Agency, Information. c Springer-Verlag Berlin Heidelberg 2010.

7. http://www.deponet.uz/sites/default/files/otchyot _cd_9_mes_2021_0.pdf

8. https://www.uzse.uz/isu_infos?page=3

9. Djumanov A. K., Kim H. N. LEGAL ANALYSIS OF MAIN TYPES OF CORPORATIONS IN GERMANY AND GREAT BRITAIN //Herald pedagogiki. Nauka i Praktyka. - 2021. - T. 1. - №. 5 .

10. Батирова К.Ю. Фондовый рынок как правовая категория. Обзор законодательства РУз 2/2019. https://library-tsul.uz/uzbekiston-onunchilik-ta-liliuzbek-law-review-obzor-zakonodatelstvauzbekistana-1-2019-jil-2/ 
The American Journal of Political Science Law and Criminology

(ISSN - 2693-0803)

VOLUME 04 ISSUE 01 Pages: 47-51

SJIF IMPACT FACTOR (2020: 5. 453) (2021: 5 • 952)

OCLC - 1176274523 METADATA IF - 7.659

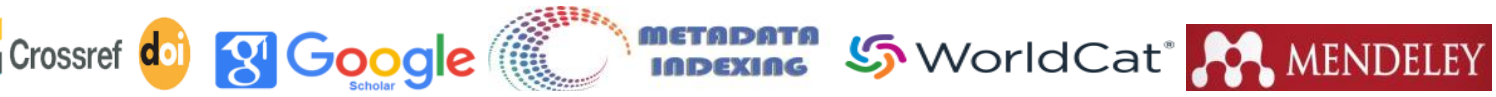

Publisher: The USA Journals

11. Портфельне інвестування: Навч. посібник / А. А.

Пересада, О. Г. Шевченко, Ю. М. Коваленко, С. В.

Урванцева. - К.: КНЕУ, 2004.

12. Petri Mantysaari. The Law of Corporate Finance: General Principles and EU Law. Volume I: Cash

Flow, Risk, Agency, Information. c Springer-Verlag

Berlin Heidelberg 2010. P-18

13. Морозова Л.А. Теория государства и права.

Учебник. 4-издание. C.204.

https://www.msmsu.ru/userdata/manual/doc/kaf/s ud_med/

14. Зенькович Е.В. Рынок ценных бумаг: административно-правовое регулирование. (под ред. Л.Л. Попова) ("Волтерс Клувер", 2007)

15. Иоффе О.С. Избранные труды по гражданскому праву: из истории цивилистической мысли. Гражданские правоотношения. Критика теории "хозяйственного права". М., 2000. С. 537 - 538.

16. Мамараимова Гулрух ПРАВОВЫЕ ПРОБЛЕМЫ ТРАНСГРАНИЧНОГО НАСЛЕДОВАНИЯ ИНТЕЛЛЕКТУАЛЬНОЙ СОБСТВЕННОСТИ // Review of law sciences. 2020. №Спецвыпуск. URL: https://cyberleninka.ru/article/n/pravovyeproblemy-transgranichnogo-nasledovaniyaintellektualnoy-sobstvennosti (дата обращения: 20.12.2021). 